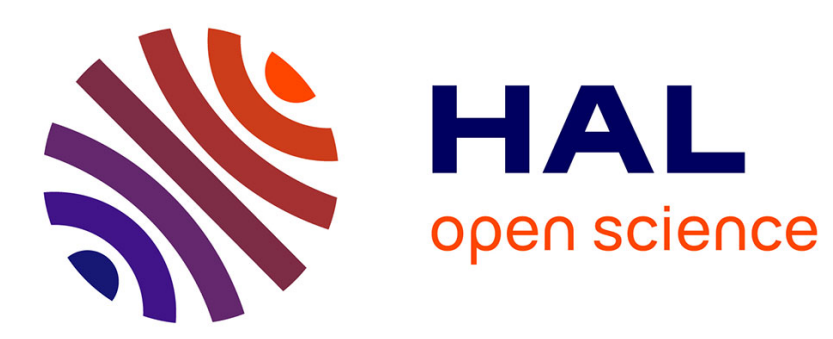

\title{
Hackers vs States: Subversion, Repression and Resistance in the Online Public Sphere
}

Félix Tréguer

\section{To cite this version:}

Félix Tréguer. Hackers vs States: Subversion, Repression and Resistance in the Online Public Sphere. Droit et Société, 2015, 91 (3), pp.639-652. 10.3917/drs.091.0639 . halshs-01637939

\section{HAL Id: halshs-01637939 \\ https://shs.hal.science/halshs-01637939}

Submitted on 18 Nov 2017

HAL is a multi-disciplinary open access archive for the deposit and dissemination of scientific research documents, whether they are published or not. The documents may come from teaching and research institutions in France or abroad, or from public or private research centers.
L'archive ouverte pluridisciplinaire HAL, est destinée au dépôt et à la diffusion de documents scientifiques de niveau recherche, publiés ou non, émanant des établissements d'enseignement et de recherche français ou étrangers, des laboratoires publics ou privés. 


\title{
Hackers vs States: Subversion, Repression and Resistance in the Online Public Sphere
}

\author{
Félix Tréguer
}

Droit et Société 91/2015, pp. 639-652

\begin{abstract}
Résumé Hackers contre États : subversion, répression et résistance dans l'espace public numérique

L'article utilise le concept de «citoyenneté insurrectionnelle » pour analyser les usages militants d'Internet qui subvertissent les règles de droit encadrant la liberté d'expression et l'espace public démocratique. II examine ensuite les politiques répressives des États visant à contrer ces illégalismes, ainsi que les stratégies de contournement et de résistance mises en œuvre par les militants. À partir de trois exemples - Copwatch (surveillance citoyenne de la police), WikiLeaks (fuite de documents confidentiels) et The Pirate Bay (plateforme peer-topeer de partage d'œuvres culturelles) -, l'article montre comment la cyberculture conduit à l'émergence d'un nouveau mouvement de défense des droits humains visant à légaliser des pratiques militantes « para-légales » et à transformer le rapport de force entre la société civile et l'État dans l'espace public numérique.
\end{abstract}

Désobéissance - Espace public - Hackers - Liberté d'expression - Mouvements sociaux Para-légalité.

Summary The article uses the concept of "insurgent citizenship" to analyze the way online activists subvert the laws regulating freedom of expression and the democratic public sphere. It examines the state's repressive response aimed at restoring legality and the strategies that activists develop to circumvent and resist repression. By focusing on three groups of insurgent citizenship - Copwatch (a website documenting and denouncing police abuse in France), WikiLeaks (an organization devoted to leaking secret information) and The Pirate Bay (a peerto-peer file-sharing platform) -, the article shows how cyberculture is giving way to a new human rights movement seeking to legalize "para-legal" militant practices and change the power balance between civil society and the state in the online public sphere.

Disobedience - Freedom of expression - Hackers - Internet - Para-legality -Public sphere Social movements. 
Paris, May $24^{\text {th }}, 2011$. It was a sunny morning when former President of France Nicolas Sarkozy entered the large tent that had been put up on the site of the Tuileries gardens to give the opening speech of the eG8 forum. Weeks earlier, the French Presidency's announcement of this international event focusing on the digital economy had immediately sparked skepticism and hostility among civil society groups wary of a government "power grab" over the Internet. So in his speech, President Sarkozy sought to explain his approach, defending the legitimacy of representative governments to transpose the underlying principles of communications law to the global information network.

The states we represent need to make it known that the world you represent [i.e. the Internet] is not a parallel universe, free of legal and moral rules and more generally of all the basic principles that govern society in democratic countries [...]. Nobody can nor should forget that these governments are the only legitimate representatives of the will of the people in our democracies. To forget this is to run the risk of democratic chaos and hence anarchy [...]. A social contract cannot be drawn up by simply lumping together individual aspirations.

If the aim of the eG8 was to build trust between those attached to the protection of human rights on the Internet and representative governments, it undoubtedly failed. During the two days of the forum, speakers were often interrupted by audience members. Against the French President's attempt to legitimize Internet regulation in the name of representative democracy, many activists, scholars and entrepreneurs instead denounced what they saw as illegitimate restrictions on the freedom of communication, invoking the very principles on which representative governments are based: the democratic ideal and the rule of law.

What played out in the institutional arena of the eG8 offers a glimpse of a wider struggle about citizenship. Communications law (from press laws to copyright law) and its attached practices (from journalistic ethics to state secrets) regulate what Jürgen Habermas calls the "public sphere" (öffentlichkeit) the conceptual space for democratic debate. ${ }^{1}$ These laws fashion the flow of ideas, opinions, information and cultural artifacts, from which we make sense of the world and articulate a vision of how it ought to be. As such, they define part of the legal domain of democratic citizenship.

Today, this legally-defined citizenship is increasingly challenged as activists influenced by the social worlds of Internet subcultures use both technology and the law itself to subvert the public sphere's existing legal norms. Their disobedient practices give way to what socio-anthropologist James Holston calls an "insurgent citizenship": like the grassroots mobilizations and everyday practices that James Holston studies in the margins of urban public spaces in Brazil, the Internet's insurgent citizens cross legal boundaries to, as J. Holston writes, "parody, derail or subvert state agendas," and expand lived citizenship to new realms. ${ }^{2}$ In so doing, they trigger a reaction from the elites, who seek to maintain the status quo through segregation and violence so as "to restore old paradigms of order". ${ }^{3}$

To legitimize their practices and resist the symbolic and material violence usually attached to illegality, the Internet's insurgent citizens and their defenders often use the legal language, categories or imaginaries - in particular those attached to the human right to freedom of expression. In that sense, they give another evidence of "the cultural power of law" in shaping resistant practices. ${ }^{4}$ I propose to

1. Jürgen HABERMAS, The Structural Transformation of the Public Sphere: An Inquiry Into a Category of Bourgeois Society, Cambridge MA: MIT Press, 1991.

2. James Holston, "Spaces of Insurgent Citizenship”, in Leonie SANDERCOCK (ed.), Making the Invisible Visible: A Multicultural Planning History, Oakland: University of California Press, 1999, p. 47.

3. ID., Insurgent Citizenship: Disjunctions of Democracy and Modernity in Brazil, Princeton: Princeton University Press, 2008, p. 14.

4. Sally Engle Merry, "Resistance and the Cultural Power of Law", Law and Society Review, 29 (1), 1995, p. 11-26. 
capture this ambivalent relationship to legality through the concept of "para-legality", where the polysemy of the prefix "para-" can mean either "beyond" or "shield against". Para-legality thus serves to designate both a spectrum of discourses and practices operating under overarching legal principles (like human rights) but beyond specific laws and their interpretation by state actors, as well as strategies aiming to shield insurgent citizens against law enforcement in the name of such higher principles.

This article builds on ongoing doctoral research looking at this dynamic conflict over the legal rules that define citizenship in the online public sphere. For the later, I adopt "grounded theory methodology", based on observer-participant fieldwork as a legal analyst in a prominent European "digital rights" advocacy group that took part in the legal and political controversies discussed here. I collected an important set of data, including policy documents, case law, news articles, public interventions and written material by both "insurgent citizens" and their allies as well as policy-makers. This material was later complemented with semi-structured qualitative interviews with activists. In the course of this "engaged research", ${ }^{5}$ I assumed different roles - the activist, the advocate, the scholar -, while working reflexively to make sense of the community in which I was taking part, and in particular of its relationship to the law.

In what follows, I focus on three groups deemed illegal by public authorities: Copwatch, a website documenting and denouncing police abuse in France; WikiLeaks, the organization devoted to leaking secret information; The Pirate Bay, a file-sharing platform allowing for the exchange of cultural works over the Internet. I start by presenting these movements, briefly showing how each of them occupies a specific location in relation to cyberculture and overtly defies different sets of rules while invoking legality to legitimize their conduct (I). I then examine the state's repressive attempt to reassert the political order against these para-legal practices and claims, as well as the limits of legal mobilization in resisting such repression (II). Finally, I turn to the way insurgent citizens and their allies in civil society react by organizing para-legal strategies aimed at defending themselves against law enforcement (III).

\section{The Net's Insurgent Citizens and the Subversion of the Public Sphere}

From the beginning, the Internet has been construed as an empowering and subversive technology. Many computers research communities and networks instrumental in its development were deeply influenced by the cybernetic and counter-cultural criticisms of the Cold War technocracy. ${ }^{6}$ From the early times of networked computing in the 1960's to later movements in cyberculture such as hacker groups, free software communities or the 1990's "digeratis", post-war cybernetician Norbert Wiener's axiom equating the free flow of information with social "homeostasis" acted as a model. Benjamin Loveluck has termed this multifaceted philosophy "informational liberalism": away from the "freedom to inform" of the media, informational liberalism sees the "freedom of information" as the basis of political autonomy. ${ }^{7}$ As a result, decentralization and communicative freedom was coded into the "network of computer networks" these communities were building.

To the extent that many legal rules inhibit free communication flows, transgression of the law has naturally been a recurring theme in the history of informational liberalism. Examples include Buckminster Fuller's call to explore alternative lifestyles in "outlaw areas", the rebellious figure of the "cyberpunk"

5. Stefania MILAN, "Toward an Epistemology of Engaged Research", International Journal of Communication, 4, 2010, p. 856-858.

6. Fred TURNER, From Counterculture to Cyberculture: Stewart Brand, the Whole Earth Network, and the Rise of Digital Utopianism, Chicago: University of Chicago Press, 2006, p. 11-41.

7. Benjamin LOVELUCK, Freedom Through Information: A Political Genealogy of Informational Liberalism and Self-Organization on the Internet, PhD thesis, Paris: EHESS, 2012. 
in science fiction literature, the "temporary autonomous zones" theorized by "ontological anarchist" Hakim Bey, up to the cyberlibertarians' rejection of the applicability of state sovereignty to the Internet in the 1990's. By then, legal transgression was not just a normative goal but seemed to have become the defining feature of the Internet: its global scope, the massive scale of its communication flows, its decentralized governance structures and the new forms of collective actions it enabled all converged to create a "major disruption in the way we regulate communication and information technology", challenging the state jurisdiction on the public sphere. ${ }^{8}$

Internet-based insurgent citizenship practices ensue from the way individual and collective actors revisit the traditional functions of the public sphere with the subversive ideas and tools of informational liberalism. As radical democracy scholars have noted, the Internet has enlarged the public sphere, opening a space where once excluded citizen groups can act at its outskirts to challenge dominant discourses and resist power, bringing about a more agonistic public sphere. ${ }^{9}$ But from a legal perspective, some of these groups do so by subverting the rules that regulate freedom of expression and normalize democratic discourse in line with deliberative democratic conceptions. I now present three such movements of insurgent citizenship.

The first group is Copwatch, ${ }^{10}$ an anonymous team of volunteer contributors publishing many online texts on police misconduct, often illustrated with photographs or videos shot on the street. This material aims to document and denounce various abuses, such as violence during brutal arrests, provocations of protesters by members of the force, or judicial permissiveness toward several officers accused of corruption. According to Copwatch's editors, who are sometimes presented as far-left activists, their goal is to show "the result of a securitarian policy pushing cops to do a dirty job, because they have numbers, orders, and hierarchy." In documenting systemic police abuse, copwatching undertakes the same task as some journalists or sociologists. But it radically differs from these more traditional public sphere participants because copwatchers often resort to immoderate and sometimes violent expressions against the police, in line with early counter-hegemonic forms Internet-based activism and their focus on subjectivity. ${ }^{11}$ In fact, Copwatch's contributors make a claim of not abiding by any "official" deontology. Accordingly - and even though most texts carry an analytical, if at times satirical, style -, some posts show plain rage: "We will not hesitate to use harsh terms against the police, because we think of this institution as the common tomb of mankind, the mass grave of evolution, the daily killing of both deontology and ethics. We will be unequivocal [in denouncing it]." For all their verbal aggressiveness, they also claim that their activities are legal, giving their own interpretation where the line of legality should be drawn: "we don't transgress the laws," they argue in an interview. "We've never disclosed confidential information such as officers' physical addresses or family life. If we have doubts, we do not disclose."

The second group is WikiLeaks. Its founder, Julian Assange, comes from an influential branch of the hacker movement called the "cypherpunks", a community of people passionate about cryptography and its subversive political implications that was active in the 1990's. By launching WikiLeaks in 2006, J. Assange was one of the first to actually implement the radical idea of using the Internet and cryptog -

8. Milton MuELLER, Networks and States: The Global Politics of Internet Governance, Cambridge MA: MIT Press, 2010, p. 4.

9. Lincoln DAHLBERG, “The Internet, Deliberative Democracy, and Power: Radicalizing the Public Sphere”, International Journal of Media and Cultural Politics, 3 (1), 2007, p. 47-64.

10. Available at: <http://copwatchnord-idf.info $>$.

11. Sian Sullivan, Andre SPICER, and Steffen BoHM, "Becoming Global (Un)Civil Society: CounterHegemonic Struggle And The Indymedia Network”, Globalizations, 8 (5), 2012, p. 703-717. 
raphy to systematically and anonymously leak state secrets. ${ }^{12}$ Making secret but public interest information known to the public is an important function of the media. For this very reason, the European Court of Human Rights (ECHR) even elevated the protection of journalistic sources as the "cornerstone" of freedom of expression in 1996 in its landmark case Goodwin v. United Kingdom. ${ }^{13}$ But by using encryption to facilitate massive leaks of state and corporate secrets - such as during the "Cablegate", when in December 2010 WikiLeaks and media partners started releasing a trove of thousands of US diplomatic documents -, organizations such as J. Assange's bring the networked public sphere into uncharted legal territories. J. Assange, however, simply claims to be exerting journalists' rights to leak confidential documents that are of public interest in accordance with established legal standards, such as the US First Amendment.

We have now in our four-year history had over 100 legal attacks of various kinds and have been victorious in all of those matters, he said in 2010. So if you want to talk about the law, it's very important to remember the law is not simply what powerful people would want others to believe it is [...]. The law, rather, is what the Supreme Court in the land in the end says it is, and the Supreme Court in the case of the United States has an enviable Constitution on which to base its decisions. ${ }^{14}$

That being said, J. Assange is also aware that his own interpretation might be lost in political intricacies of the courts: "whether the Supreme Court makeup now is such that it keeps to its traditions or proposes a radical reassessment of the power of the First Amendment and the US Constitution remains to be seen," he warns. ${ }^{15}$

The third group is The Pirate Bay, one of the most famous incarnations of the file-sharing movement. Though it might first appear less relevant for emancipatory politics, The Pirate Bay can also be viewed as an insurgent movement offering a radical reinterpretation of a traditional function of the media ecosystem, that of circulating cultural artifacts. Founded in 2001 in Sweden, The Pirate Bay has become one of the most prominent avatars of an insurgent practice that carries on the project of turning the Internet into a universal library and of upsetting the domination of the cultural industries on the public sphere. Allowing people to share their Internet bandwidth to exchange cultural works via the BitTorrent protocol, the platform promotes a "right to copy" as the building block of the knowledge commons advocated by the "free culture movement" and as a radical way of fighting against the excesses of "intellectual property" laws. ${ }^{16}$ In their fight against copyright, the Pirate Bay's team members exploit the ambiguities of the law. For instance, they explain that they should not be held liable since they do not host any infringing content and merely propose an online index allowing people to share content. When they receive takedown requests from rights holders (usually located in the US), they also allege that the US law invoked in these notices (the Digital Millenium Copyright Act) does not apply to them, and pretend that The Pirate Bay is fully legal under Swedish law. At the same time, they make clear that "any complaints from copyright and/or lobby organizations will be ridiculed and published at the site", meaning that they have no intention to facilitate copyright enforcement. Behind their legal posturing, their defiant tone suggests that their attitude towards the law is in fact overtly disobedient.

12. Andy GreEnBERG, This Machine Kills Secrets: How WikiLeaks, Hacktivists and Cypherpunks aim to free the world's information, New York: Dutton, 2012.

13. Goodwin c. Royaume-Uni, $\mathrm{n}^{\circ}$ 17488/90, March 7 1996, § 39, CEDH 1996-II.

14. Richard STEngel, “TIME's Julian Assange Interview: Full Transcript”, Sahara Reporters, December 7 2010, <http://saharareporters.com/2010/12/07/times-julian-assange-interview-full-transcript $>$.

15. Ibid.

16. Eduardo M. Penalver and Sonia Katyal, Property Outlaws: How Squatters, Pirates, and Protesters Improve the Law of Ownership, New Haven: Yale University Press, 2010. 
While all of these movements of insurgent citizenship influenced by informational-liberalism use the Internet to challenge the norms regulating the public sphere, they also make an effort to present their practices as not only legitimate but also legal. Here, para-legality is part of a dialectic process in the construction of lived citizenship: these groups suggest that regardless of what the state and the courts say, these should be legal practices recognized as legitimate democratic practices protected under human rights law or some abstract principle of justice. In that sense, they engage in the creation of heterodox legal meanings - what American legal scholar Robert Cover calls "jurisgenesis". ${ }^{17}$ But this "informational-liberal jurisgenesis", taking place from outside the institutional sphere, opens the door to repression: as R. Cover notes, "interpretation always takes place in the shadow of coercion." ${ }^{18}$

\section{Intensifying State Repression to Restore the Political OrderThe early} anarchist project of a cyberspace completely emancipated from traditional sovereignty now seems all but chimerical. Against the "lawless Internet" and in the name of the "general will" invoked by Nicolas Sarkozy at the eG8, states have reasserted the rules of the public sphere, in particular by regulating and pressuring technical intermediaries, such as telecom operators and hosting platforms. ${ }^{19}$ In this section, I present some legal and extra-legal measures taken by states to restrict freedom of expression online and discuss why insurgent citizens face hurdles in getting protection from the courts.

\section{II.1. Litigation, Retaliation, Legislation: the Forms of State Repression}

To foreclose practices of insurgent citizenship, governments often bend or escape some of the safeguards of freedom of expression, choosing from a range of legislative, judicial and extra-legal tactics according to the specific arrangement at play. To justify repression, they also deny these insurgent movements any legitimacy in engaging in the democratic public sphere.

When Copwatch first went online in September 2011, French police unions immediately denounced it as an "anti-cop" website, offending the reputation of police forces. The former Minister of the Interior, Claude Guéant, decided to bring charges against it, and after a fast-track procedure, the tribunal de grande instance in Paris ordered that the website be blocked by French Internet access providers. Besides violating the privacy of several police officers for publishing screen-shots of their social networks profiles, copwatchers were deemed to engage in slander for saying that the police was the "common tomb of mankind." They were also found guilty of defamation because of a text saying that the border police "was trained to hunt migrants, to humiliate them and torture them psychologically." The government said it was forced to seek an injunction against telecom operators rather than pressing charges against individual authors because they published anonymously. However, the activists have a different

17. Robert M. COVER, “The Supreme Court, 1982 Term. Foreword: Nomos and Narrative”, Faculty Scolarship Series, paper $\mathrm{n}^{\circ} 2705,1983$.

18. Ibid, p. 40.

19. Jack GoldSMITH and Tim WU, Who Controls the Internet?: Illusions of a Borderless World, Oxford: Oxford University Press, 2006. 
view, alleging that their identities were actually easy to find. Instead, they see the government's legal strategy as a deliberate move to avoid any contradictory debate which would have given copwatchers a judicial stage to engage in a public debate on police brutality. As a consequence of this procedural choice, and because Copwatch's authors chose to remain anonymous in order to avoid sentencing, they did not have any legal representation during the proceedings. Later, the Minister defended the prosecution saying that, "to ensure police deontology, there is the judiciary, the hierarchy, the national commission for police deontology." One of the trial's goals was to deny "ordinary" citizens the right to also play that role from outside institutional arenas.

In the case of WikiLeaks, the priority of the governments involved in the Cablegate controversy and in particular that of the US government - was to delegitimize WikiLeaks' claim to be doing journalist work. ${ }^{20}$ So, in part to avoid setting an unfavorable legal precedent, they chose to engage extra-legal retaliation. In a matter of hours after the first releases of the Cablegate, WikiLeaks suffered a massive "distributed denial-of-service attack" against its servers, most probably from one or several state actors (DDoS attacks consist in flooding a server with requests, to the point of rendering it temporarily unusable and the hosted websites inaccessible). US Vice-President Joe Biden declared that Julian Assange was a "high-tech terrorist" for disclosing state secrets while Senator Joe Lieberman called on any "company or organization that is hosting WikiLeaks to immediately terminate its relationship with them." First its hosting provider Amazon, then its domain name provider EveryDNS, and finally its payment system providers Paypal, Visa and Mastercard all unilaterally pulled out of their business relationship with WikiLeaks. Its very survival was at risk in the country of the First Amendment. In response, J. Assange and his team strove to ensure that WikiLeaks would remain accessible via other domain names and sought a new hosting provider. The website finally landed in Roubaix, France, in one of the data centers of the hosting company $\mathrm{OVH}$. But there too, the French government decided not to press charges and instead resorted to extra-judicial maneuvers to pressure $\mathrm{OVH}$ into taking the site down. But in the absence of a judicial decision to the contrary, the company declared that it would keep on hosting the site. After its failed attempt, the French government nevertheless continued to resist WikiLeaks' influence in the public sphere. Asked by two parliamentarians about the content of US diplomatic cables mentioning a potential case of corruption of foreign officials by a French company in Turkmenistan, the government stated that it would not "comment on the content of the website WikiLeaks, nor to any press article refer ring to it." A posture seeking to exclude it from the institutionalized channels of democratic control. Meanwhile, WikiLeaks' source, former US soldier Chelsea Manning, was sentenced in the summer of 2013 by a US military court to 35 years in prison under the 1917 Espionage Act for disclosing hundreds of thousands of military and diplomatic documents.

As for The Pirate Bay and the file-sharing movement, they have given way to an inflation of copyright enforcement legislation and litigation. When the first file-sharing system Napster came along in 1999, it became clear that sticking to the legal status quo would do little to help copyright-holders prevent what they deem to be "theft" of their "intellectual properties". Legal battles in courts and parliaments ensued to bolster repression. By 2005, both European Union (EU) member states and the US had not only adopted sanctions and enforcement mechanisms to target end-users, but also civil and criminal provisions to sue intermediaries providing the technical infrastructures for file-sharing. On the basis of these laws, server seizures were conducted against The Pirate Bay in Sweden and in the Netherlands.

20. Yochai BENKLER, "A Free Irresponsible Press: Wikileaks and the Battle over the Soul of the Networked Fourth Estate”, Harvard Civil Rights-Civil Liberties Law Review, 46 (2), 2011, p. 311-397. 
Courts in at least ten EU countries have also issued blocking injunctions against The Pirate Bay (in Belgium, Denmark, Finland, Germany, Greece, Ireland, Italy, Netherlands, Sweden, the United Kingdom and France). Finally, in their home country Sweden, the three founders of the platform were sentenced to shared damages of 5,000,000 euros and prison sentences from 8 to 12 months.

\section{II.2. The Judicial Arena: A Difficult Road to Walk for Insurgent Citizens and Their Defenders}

The repressive policies established by representative governments to counter insurgent practices online lead to important legal controversies. Insurgent groups or other actors better equipped to defend the informational-liberal jurisgenesis at the institutional level get involved, leveraging human rights law as a legal resource to resist enforcement measures. But when they can appeal to judicial arenas, they are faced with a set of constraints which, at this point in time, seem to preclude any substantive reassessment of the right to freedom of expression.

To resist repression and seek the recognition of their jurisgenesis, movements of insurgent citizenship increasingly benefit from the support of advocacy groups. Whether they are specialized in Internet policy and come from the culture of informational liberalism - such as the San Francisco-based Electronic Frontier Foundation founded in 1990 by counter-cultural icons and cypherpunks ${ }^{21}$ - or devoted to the defense of freedom of expression of media entities or to human rights in general, a number of them occasionally intervene in court proceedings.

These advocacy groups have recently gained the support of key international organizations working on human rights, such as the United Nations (UN) as well as the Council of Europe. For instance, in its 2011 report to the United Nations Human Rights Council, former UN Special Rapporteur on freedom of expression Frank La Rue strongly criticized the type of website blocking measures that have multiplied in Europe since 2004, and which were used against both Copwatch and The Pirate Bay. ${ }^{22}$ In the aftermath of the extra-legal measures taken against WikiLeaks, the Council of Europe also denounced "politically motivated pressure exerted on privately operated Internet platforms and online service providers, and of other attacks against websites of independent media, human rights defenders, dissidents, whistleblowers and new media actors."

But while they sometimes strike down over-broad and arbitrary enforcement measures as disproportionate, human right courts have so far resisted the informational-liberal jurisgenesis. For instance, the ECHR tends to construe the Internet as a dangerous space calling for wider restrictions on freedom of expression than those existing in traditional media. ${ }^{23}$ Based on this premise, the court is keen on reinforcing the "duties and responsibilities" falling on public sphere participants when they communicate online. In its 2007 ruling in Stoll v. Switzerland, the ECHR held:

In a world in which the individual is confronted with vast quantities of information circulated via traditional and electronic media and involving an ever-growing number of players, monitoring compliance with journalistic ethics takes on added importance. ${ }^{24}$

The court also holds that the same rules apply to all speakers: mainstream journalists, activists or even ordinary citizens. Given its approach to the Internet, and considering its jurisprudence in cases in-

21. Johnny NHAN and Bruce A. CARROLL, "The Offline Defense of the Internet: An Examination of the Electronic Frontier Foundation”, SMU Science and Technology Law Review, 15 (3), 2012, p. 389-403.

22. Frank LA RUE, 2011 Report of the Special Rapporteur on the promotion and protection of the right to freedom of opinion and expression, United Nations, 2011.

23. Félix TrégUer, "Internet dans la jurisprudence de la Cour européenne des droits de l'homme", Revue des droits et libertés fondamentaux, chron. $\mathrm{n}^{\circ} 13,2013$.

24. Stoll c. Suisse [GC], n 69698/01, 12th December 2007, § 151, CEDH 2007-V. 
volving the publication of confidential diplomatic documents or insults to police officers, the court would certainly rule against WikiLeaks or Copwatch. As for The Pirate Bay, the ECHR rejected in March 2013 the request introduced by two Pirate Bay's founders to challenge their condemnation by Swedish tribunals.

A number of possible factors explain why the informational-liberal casuistry of human rights often fails in the courts of liberal democracies. First, there is the traditional critique of the legal field as an instrument of domination, sometimes evidenced by the collusion between judges and the state or, as was denounced by one of The Pirate Bay's co-founders, with rights-holders. ${ }^{25}$ In Europe, there are also important shortcomings in the judicial strategies of insurgent citizens and their allies in civil society. The later can be attributed to the lack of legal opportunities ${ }^{26}$ - and in particular the constraints that continental legal systems entail for activists and the culture of legal-positivism that such systems favor $-{ }^{27}$ or to the weakness of positive legal protections for freedom of expression (as compared to the right to privacy). Finally, in engaging with the courts, many of these groups also lack the material resources that allow for successful human rights causes. ${ }^{28}$

That being said, besides these common hurdles for legal mobilization by social movements, there is a major and overarching constraint: the common perception of the Internet as an unruly social space. Faced with the legal disruption and "democratic chaos" created by both the Internet's technical features and its insurgent citizens, judges tend to reject the informational-liberal jurisgenesis. Instead, they reckon that tougher restrictions on rights and freedoms are necessary to reassert the unity of the law and the supremacy of state jurisdiction. Yielding to the "lawlessness" rhetoric and reaffirming the ideology of the social contract, they side with what Robert M. Cover terms the "hermeneutic of jurisdiction": the judge becomes "an agent of state violence and employer of that violence against the 'private' disorder of movements, communities, unions, parties, 'people,' 'mobs'." ${ }^{29}$ From a historical perspective, the setbacks suffered by the rule of law during the past decade in the face of rising securitarian policies and discourses has also undermined their ability to resist state violence. Consequently, at least in the shortterm, insurgent citizenship movements should not count on what Éric Agrikoliansky calls the "judicial system's openness to protesting claims" to see their actions gradually recognized as legal democratic practices. ${ }^{30}$

\section{Resistance Through Both Disobedience and Legal Reform}

How to resist online censorship when it is sanctioned by governments and by the courts? Insurgent citizens and their advocates adopt two para-legal strategies aimed at shielding insurgent citizens

25. Peter Sunde, "Biased Judge also in the ECHR", Copy me happy, April 3 2013, <http://blog.brokep.com/ 2013/04/03/biased-judge-also-in-the-echr/>.

26. Chris Hilson, "New Social Movements: The Role of Legal Opportunity", Journal of European Public Policy, 9 (2), 2002, p. 238-255.

27. Stephen MeILI, "Cause Lawyers and Social Movements: A Comparative Perspective on Democratic Change in Argentina and Brazil”, in Austin SARAT and Stuart SCHEINGOLD (eds.), Cause Lawyering: Political Commitments and Professional Responsibilities, Oxford: Oxford University Press, 1998, p. 497.

28. Charles R. EPP, The Rights Revolution: Lawyers, Activists, and Supreme Courts in Comparative Perspective, Chicago: University Of Chicago Press, 1998, p. 44-70.

29. Robert M. COVER, “The Supreme Court, 1982 Term. Foreword: Nomos and Narrative”, op. cit., p. 55.

30. Éric Agrikoliansky, "Les usages protestataires du droit", in Éric AGRIKOLIANSKY, Isabelle SOMMIER and Olivier FILLIEULE (dir.), Penser les mouvements sociaux, Paris: La Découverte, 2010, p. 225-243. 
against repression. The first radicalizes insurgency through "electronic civil disobedience", mobilizing technical knowledge to circumvent and protest against law enforcement. The second strategy invests in institutional channels to advocate legal change and legalize insurgent practices.

\section{III.1. Technical Strategies: Hacktivist Civil Disobedience to Circumvent and Protest Censorship}

Despite repression and judicial inertia, there is a tool that insurgent citizenship movements can still rely upon: the "free and open" Internet. In the mid-2010's, the Internet retainsarchitectural features allowing motivated activists to use their technical know-how to act as self-proclaimed "guardians of the Internet" and defeat what they see as illegitimate state repression.

The loose communities of engineers and computer experts that played a role in enabling insurgent citizenship practices are exploiting the Internet features to resist censorship by rehabilitating the action repertoire of "electronic civil disobedience" developed by the first hacktivist movements of the 1990's. They can allow users to circumvent blocking measures - for instance by reproducing the targeted content in many different locations of the Internet -, or voice their opposition by waging DDoS actions, website defacement and other protest tactics that are illegal under computer crime laws. ${ }^{31}$ In both cases, censorship has the paradoxical effect of giving the targeted information even more publicity (a phenomenon known as "the Streisand effect"), as it draws attention to state repression and sparks a debate on its legitimacy.

In the case of Copwatch, from the moment the French government announced that it would bring charges to block the website, dozens of hactivists took upon themselves to create "mirror sites", that is to say perfect copies replicating Copwatch on other servers immune to the blocking measures. On its own website, the group "Telecomix" - self-described as a "sociocyphernetic telecommunist feminist cluster of Internet and data loving bots and people [...] striving to protect and improve the Internet and defend the free flow of data" - set up an index of these mirror sites. When I asked one member of the collective why he was taking part in this effort, he replied in the pure vein of informational liberalism.

Data must flow. We did it in Ivory Coast, in Egypt, in Tunisia and elsewhere. Why wouldn't we do it in this case? [...] I don't agree with the tone used [by Copwatch authors], but I'm even more opposed to censorship.

Thanks to mirror sites, Copwatch has remained easily accessible through a simple query in a search engine. "We'll never thank hackers enough for their struggle in favor of freedom", said one member of the collective.

A similar sequence occurred during WikiLeaks' Cablegate. Worldwide, many people collaborated to create several hundreds of mirror sites, each giving access to the diplomatic cables released by the organization. Meanwhile, in retaliation, hacktivists operating under the banner of the informal group "Anonymous" launched DDoS attacks against Paypal, Mastercard, Visa, Amazon, and even the website of Senator Lieberman to protest against their extra-legal censorship attempt. These mostly symbolic actions drew considerable media attention, and were defended by Free Software activist Richard Stallman as the online equivalent of a sit-in. ${ }^{32}$

Lastly, in spite of recurrent legal troubles, The Pirate Bay's volunteers have managed to avoid prolonged inaccessibility, priding themselves on having created the "galaxy's most resilient BitTorrent site."

31. Molly SAUTER, The Coming Swarm: DDOS Actions, Hacktivism, and Civil Disobedience on the Internet, New York: Bloomsbury, 2014.

32. Richard Stallman, "The Anonymous WikiLeaks Protests Are a Mass Demo against Control", The Guardian, December 17 2010, <http://www.guardian.co.uk/commentisfree/2010/dec/17/anonymouswikileaks-protest-amazon-mastercard $>$. 
To do so, they can rely on a range of solutions, depending on the situation: relocating servers, fine-tuning file-sharing techniques or spreading the use of cryptographic and other alternative tools that allow users to escape copyright enforcement measures. In solidarity with The Pirate Bay, Anonymous groups have also conducted DDoS actions against the websites of right-holders organizations and those of the law firms working for them.

However, states have traditionally reacted forcefully to online acts of civil disobedience, and these past years have only confirmed earlier concerns. ${ }^{33}$ Hacktivists too come to embody an instance of insurgent citizenship, leading to a repressive escalation as states criminalize circumvention techniques and as online protesters suffer harsh arrests, indictments and exemplary punishment under computer crime laws.

\section{III.2. Institutional Strategies: Protecting Insurgent Citizens Through Legal Change}

So to defend civil liberties in the digital environment and resist repression, activists work from within the institutional channels of governments. They mobilize legal discourse, political skills and innovative uses of technology to campaign and influence state actors, the way law is made and the values it reflects - an approach pioneered by the Electronic Frontier Foundation and which has already played an important role in legislative debates on Internet regulation. ${ }^{34}$ It is not just specialized advocacy groups (like the one in which I took part) who do so: WikiLeaks has worked with local organizations in Iceland in a so-far unsuccessful attempt to turn the country into a legal "safe haven" for free communications. Pirate Parties - whose main proposal includes a reform of copyright and patent laws, but also better protections for privacy and freedom of expression - have also been taking root in the EU, although with varying degrees of success.

Groups resorting to such insider strategies have been building organizational resources to bring the ethos of informational liberalism from underground cyberculture to mainstream policy and legal debates, seeking a long-term resolution to the conflict over freedom of expression online. Hacker and free software advocacy groups, which at least in Europe have long been working in isolation, ${ }^{35}$ are increasingly collaborating with well-established international human rights NGOs and even political parties. Such capacity-building may also allow them to develop more systematic judicial strategies. In this respect, the controversies sparked in mid-2013 by whistleblower Edward Snowden on mass surveillance and privacy are acting as a catalyst, leading to a number of legal challenges and important judicial decisions on both sides of the Atlantic. Over time, it will perhaps lead judges to reconsider their often conservative approach to human rights on the Internet and also impact the right to freedom of expression, which anyway is highly intertwined with the right to privacy.

According to Gabriella Coleman, a leading anthropologist of hacktivist groups, "all signs point to this type of traditional political activity becoming more common." But, as she stresses, they will "likely exist alongside" insurgent actions and "the loosely organized acts of disobedience, defiance, and protests that have also become more frequent and visible in the last few years." For her, through this two-legged

33. Mark MANiOn and Abby Goodrum, "Terrorism or Civil Disobedience: Toward a Hacktivist Ethic", SIGCAS Computer and Society, 30, 2000, p. 14-19.

34. Yana BREINDL, Hacking the Law: An Analysis of Internet-based Campaigning on Digital Rights in the European Union, Philosophy \& Letters Faculty at the Free University of Brussels, 2011. Monica HoRTEN, The Copyright Enforcement Enigma: Internet Politics and the "Telecoms Package", New York: Palgrave Macmillan, 2011.

35. Philippe AIGRAIN, "L'activisme numérique : une réinvention inaboutie du politique", in Philippe AIGRAIN and Daniel KAPLAN (dir.), Internet peut-il casser des briques? Un territoire politique en jachère ?, Paris: Descartes \& Cie, 2013. 
approach to political change and their mastery in the political use of the Internet, geeks "are building one of the most vibrant civil liberties movements we've ever seen". ${ }^{36}$

\section{Conclusion}

To be sure, the founding pirate and outlaw utopias of the Internet's early days have given way to a very diverse movement with different social backgrounds, political cultures, organization modes and even relationships to technology or traditional political arenas. But its actors - whether they are insurgent groups, fellow hacktivists or allied advocacy groups - do share a common "set of opinions and beliefs in a population which represents preferences for changing some elements of the social structure and/or reward distribution of a society." ${ }^{37}$ They form a social movement that sees the defense of human rights as a way of altering the power balance between civil society and the state in the public sphere in favor of the former, so as to expand the realm of democratic citizenship.

The "Internet Freedom" movement - as it is sometimes called - is still in its infancy. But because of its diversity, it has already developed a complete para-legal action repertoire. First, there are the insur gent groups aiming to destabilize power relationships through para-legal practices that take place beyond common legality: despite their antagonist relationship to the state's lower legal norms, they frame their practices as consistent with higher legal principles, claiming an enlarged right to freedom of expression. Second, given the state's repressive response and the judicial acceptance of greater interferences in the exercise of human rights online, some of the movement's actors use their technical knowledge to protect citizen groups from censorship, and more generally from the state's enforcement strategies. This, in turn, leads to further repression. So, third, in order to avoid the constraints that come with non-violent but disobedient modes of political participation and break a spiraling cycle of subversion and repression, the movement's more institutional actors seek to shield insurgent citizens from repression by advocating legalization trough mobilizations in the public debate, various policy arenas and, increasingly, in the courts.

Overcoming the current stalemate, however, may first require answering the broader question of how to incorporate specific forms of disobedience and para-legality into the law and legal institutions, so as to reconcile the fiction of the social contact with a pluralist legal system capable of promoting a progressive democratic citizenship.

\footnotetext{
36. Gabriella COLEMAN, "Geeks are the New Guardians of Our Civil Liberties", MIT Technology Review, February 4' 2013, <http://www.technologyreview.com/news/510641/geeks-are-the-new-guardians-of-ourcivil-liberties/>.

37. John D. MCCARTHY and Zald N. MAYER, "Resource Mobilization and Social Movements: A Partial Theory", The American Journal of Sociology, 82 (6), 1977, p. 1217.
} 